\title{
sciendo
}

DOI 10.2478/sbe-2019-0019

SBE no. 14(1) 2019

\section{A SCALE FOR MEASURING PERCEIVED CONSTRUCTION PROJECT SUCCESS - SRI LANKAN PERSPECTIVE}

\author{
SILVA Susil Kumara \\ University of Sri Jayewardenepura, Sri Lanka \\ WARNAKULASURIYA B N F \\ University of Sri Jayewardenepura, Sri Lanka \\ ARACHCHIGE B J H \\ University of Sri Jayewardenepura, Sri Lanka
}

\begin{abstract}
:
This paper is to develop a measurement scale for perceived construction project success to be used for management studies in construction project context. First, a systematic literature review was conducted. A questionnaire was administrated to a sample of 108 construction projects and 47 (44\%) questionnaires were received. Exploratory factor analysis was carried out and required steps were followed in the process to establish validity and reliability of the measurement scale. Initially nine criteria with 25 items which can be used for evaluating and driving construction projects were found. Results of factor analysis reveal seventeen measurable items which were loaded on three dimensions/factors. Practitioners can use these criteria as a guiding framework for monitoring and driving their construction projects. This scale will be instrumental for those who are aspired to do research in construction project context. This study may be the first to discuss a measurement scale for construction project success with the viewpoints of Sri Lankan construction professionals. Also this scale has attempted to go beyond the traditional criteria and emphasize the requirement of having a long term perspective. This study add to the body of knowledge of project success criteria and construction project management.
\end{abstract}

Key words: Project Success, Success Criteria, Success Factors, Construction Industry, Measurement Scale

\section{Introduction}

The project management literature has three streams of research which are evolving around the concept of project success. They are (1) critical success factors - often considered as the independent variables that make success more likely (e.g. Gunasekera, 
2009; Tabish \& Jha, 2011; Yong \& Musttaffa, 2012; Chen, 2012; Garbharran et al., 2012), (2) project success criteria - often considered as the dependent variables and used to measure success (e.g. Lim \& Mohamed, 1999; Chan \& Chan, 2001; Hughes et al., 2004; Al-Tmeemy et al., 2011; Heravi \& Ilbeigi, 2012), and (3) third stream has immerged as the investigating the relationship between success factors and success criteria (Han et al., 2012). In the construction project management context, studies of these three streams are instrumental for the development of the construction project management knowledge (Silva et al., 2016). Though project success is the centre for all three streams, appropriate measurement scale for measuring construction project success in the present context for quantitative research is difficult to find. Development of this type of measurement scale that includes Sri Lankan perspectives is a long outstanding issue. Further, Chan \& Chan (2001) opine that though many researchers have proposed various criteria to measure construction project success, there is no general agreement. Without a valid and reliable scale, conducting empirical studies is problematic in quantitative paradigm. Failure to use a carefully developed measurement instrument can result in invalid and uninterpretable data (Hinkin et al., 1997). Further, they stress the need for developing measures to study phenomena unique to the particular industry.

Chan \& Chan (2001) stress that the concept of project success has remained ambiguously defined in the construction industry. Han et al. (2012) stress that the lack of an agreed definition for project success has long been the reason for failing to define and evaluate success. Therefore, Silva et al. (2016) have defined the concept of construction project successes after conducting a thorough literature review and provided a conceptual framework for the concept. This study is an extension of the work of Silva et al. (2016) in order to fill the existing research void. Therefore, the main aim of this study is to develop a valid and reliable measurement scale for construction project success that can be used in any construction industry research setting. Resulting measurement scale of this research will definitely be instrumental for both practitioners and academics who have aspirations to broaden the knowledge domain in construction project context.

\section{Literature Review}

Project success is the foundation for managing and controlling current projects, and for planning and orienting future projects (Chovichien \& Nguyen, 2013). Project success is an abstract concept and determining whether a project is successful is subjective and extremely complex (Parfitt \& Sanvido, 1993). Baker et al. (2008) suggest that there is no such thing as an absolute success in a project and there is only perceived success. According to Parfitt \& Sanvido (1993), the definition of project success is different for each participant, but it is based on the basic concept of overall achievement of project goals and expectations. In line with this stream of thought, Silva et al., (2016) define construction project success as "the perceived degree of achievement of predetermined performance objectives and participants' expectations of the execution of a construction facility or a service".

Criterion is a principle or standard by which anything is or can be judged (Lim \& Mohomed, 1999). According to De Wit (1988) and Cooke-Davies (2002), project success 
criteria are the measures by which success or failure of a project will be judged. Chan \& Chan (2001) define project success criteria as the set of principles or standards by which favorable outcomes can be completed within a set specifications. Table 1 provides a summary of the literature on measurement criteria, definitions and possible items/indicators for measuring perceived construction project success.

Generally, researchers have grouped success criteria into different components or factors of project success (e.g. Baccarini, 1999; Pinto \& Slevin, 1988; Shenhar et al., 2001). Criteria of construction project success are often categorized as efficiency and effectiveness measures (De Wit, 1988; Pinto \& Slevin, 1988; Belout, 1998; Atkinson, 1999). Efficiency measurers deal with time, budget and specifications, effectiveness measurers refer to achievement of project objectives, user satisfaction and the use of the project (Takim \& Adnan 2008). Silva et al. (2016) suggest to view construction project success as a two dimensional concept. Accordingly, construction project success could be viewed as the degree of achievement of efficiency (short-term perspective) and effectiveness (long-term perspective) objectives of an execution of a project.

Table 1: Literature Summary and Operationalization of the Concept

\begin{tabular}{|c|c|c|}
\hline \\
\hline \multicolumn{3}{|c|}{ 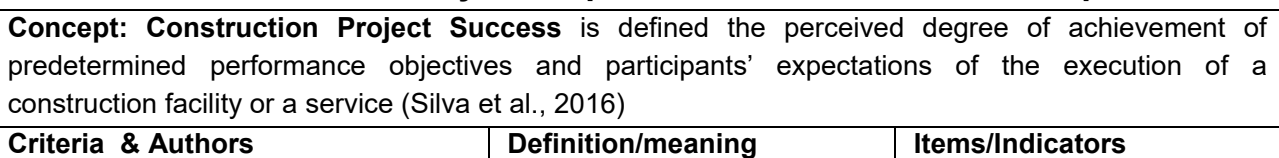 } \\
\hline \multicolumn{3}{|c|}{\begin{tabular}{ll|l} 
Lim \& Mohamed (1999), Chan \& & \\
Chan (2001), Pinto \& Slevin, (1988) & \\
Atkinson (1999), Hughes et al. & The degree of compilation of \\
(2004), Al-Tmeemy et al. (2011), & $\begin{array}{l}\text { construction work within the } \\
\text { Heravi \& Ilbeigi (2012), Khosravi \& }\end{array}$ & estimated cost budget. \\
Afshari (2011), Chovichien \& Nguyen & \\
(2013), Serradora \& Turner (2014), & \\
Elattar (2009), Wai et al. (2012) &
\end{tabular}} \\
\hline \multicolumn{3}{|l|}{$\begin{array}{l}\text { Time/Schedule - } \\
\text { Lim \& Mohamed (1999), Chan \& } \\
\text { Chan (2001), Pinto \& Slevin, (1988), } \\
\text { Atkinson (1999), Hughes et al. } \\
\text { (2004), Al-Tmeemy et al. (2011), } \\
\text { Heravi \& Ilbeigi (2012), Khosravi \& } \\
\text { Afshari (2011), Chovichien \& Nguyen } \\
\text { (2013), Serradora \& Turnerb (2014), } \\
\text { Elattar (2009), Wai et al. (2012) }\end{array}$} \\
\hline $\begin{array}{l}\text { Quality - } \\
\text { Lim \& Mohamed (1999), Chan \& } \\
\text { Chan (2001), Pinto \& Slevin, (1988), } \\
\text { Atkinson (1999), Khosravi \& Afshari } \\
\text { (2011), Hughes et al. (2004), Al- } \\
\text { Tmeemy et al. (2011), Heravi \& } \\
\text { llbeigi (2012), Chovichien \& Nguyen } \\
\text { (2013), Elattar (2009), Serradora \& } \\
\text { Turner (2014), Wai et al. (2012) }\end{array}$ & $\begin{array}{l}\text { The degree of conformity to } \\
\text { all technical specifications }\end{array}$ & $\begin{array}{l}\text { - Meeting technical } \\
\text { specifications } \\
\text { - Work stoppage due to } \\
\text { quality issues }\end{array}$ \\
\hline $\begin{array}{l}\text { Safety - } \\
\text { Lim \& Mohamed (1999), Chan \& } \\
\text { Chan (2001), Hughes et al. (2004), }\end{array}$ & $\begin{array}{l}\text { The degree to which the } \\
\text { general conditions promote } \\
\text { the completion of a project }\end{array}$ & $\begin{array}{l}\text { - } \text { Accident rate } \\
\text { - Lost days due to } \\
\text { accidents }\end{array}$ \\
\hline
\end{tabular}




\begin{tabular}{|c|c|c|}
\hline $\begin{array}{l}\text { Heravi \& Ilbeigi (2012), Khosravi \& } \\
\text { Afshari (2011), Chovichien \& Nguyen } \\
\text { (2013), Elattar (2009), Wai et al. } \\
\text { (2012) }\end{array}$ & $\begin{array}{l}\text { without major accidents or } \\
\text { injuries }\end{array}$ & \\
\hline $\begin{array}{l}\text { Client/Customer Satisfaction - } \\
\text { Pinto \& Slevin, (1988), Al-Tmeemy et } \\
\text { al. (2011), Heravi \& Ilbeigi (2012), } \\
\text { Khosravi \& Afshari (2011), Takim \& } \\
\text { Adnan (2008), Serradora \& Turner } \\
\text { (2014), Wai et al. (2012) }\end{array}$ & $\begin{array}{l}\text { The degree of satisfaction } \\
\text { over the achievement of } \\
\text { client's expectation in } \\
\text { executing the project }\end{array}$ & $\begin{array}{l}\text { - Managing client } \\
\text { complains and } \\
\text { concerns } \\
\text { Clint recommendations } \\
\text { to other parties }\end{array}$ \\
\hline $\begin{array}{l}\text { Cash-flow Management - } \\
\text { Heravi \& Ilbeigi (2012), Authors }\end{array}$ & $\begin{array}{l}\text { The availability of adequate } \\
\text { funds to carry out } \\
\text { construction work without } \\
\text { interruptions. }\end{array}$ & $\begin{array}{l}\text { - } \text { Belling performance } \\
\text { - Overall cash flow } \\
\text { management } \\
\text { - Work stoppage due to } \\
\text { financial issues }\end{array}$ \\
\hline $\begin{array}{l}\text { Profitability - } \\
\text { Takim \& Adnan (2008), Shenhar et } \\
\text { al. (2001), Heravi \& llbeigi (2012), } \\
\text { Wai et al. (2012), Chan \& Chan } \\
\text { (2001), Elattar (2009) }\end{array}$ & $\begin{array}{l}\text { Degree of financial success } \\
\text { of the project }\end{array}$ & $\begin{array}{ll}- & \text { Profit margin } \\
- & \text { Net operating income }\end{array}$ \\
\hline $\begin{array}{l}\text { Environmental Impact - } \\
\text { Chan \& Chan (2001), Heravi \& Ilbeigi } \\
\text { (2012), Khosravi \& Afshari (2011), } \\
\text { Chovichien \& Nguyen (2013), Wai et } \\
\text { al. (2012) }\end{array}$ & $\begin{array}{l}\text { The degree of negative } \\
\text { impact causing to the } \\
\text { environment due to the } \\
\text { execution of the project. }\end{array}$ & $\begin{array}{l}\text { - Lost days due to } \\
\text { environmental issues } \\
\text { - } \quad \text { Penalty on } \\
\text { environmental issues }\end{array}$ \\
\hline $\begin{array}{l}\text { Readiness for future - } \\
\text { Takim \& Adnan (2008), Wai et al. } \\
\text { (2012), Authors }\end{array}$ & $\begin{array}{l}\text { The degree of improvement } \\
\text { in terms of new technology, } \\
\text { expertise, level of } \\
\text { professional development } \\
\text { and creating a positive impact } \\
\text { in the market to face future } \\
\text { challenges }\end{array}$ & $\begin{array}{ll}\text { - } & \text { Exploration of new } \\
\text { technology } \\
\text { - } & \text { New work techniques \& } \\
\text { methods exploration } \\
\text { - } & \text { Confidence gained } \\
\text { - } & \text { Expertise development } \\
\text { - } & \text { Employee professional } \\
\text { development } \\
\text { - Creating positive } \\
\text { reputation in the } \\
\text { market } \\
\text { Development of new } \\
\text { business contacts and } \\
\text { relationships }\end{array}$ \\
\hline
\end{tabular}

\section{Methodology}

Questionnaire development - According to Hikin et al (1997), deductive approach for scale development is appropriate when some literature exist on the concept that are intended to measure. As the first step, the procedure for systematic literature review recommended by Tranfield et al. (2003) was performed in order to define the concept and identify possible criteria and items in order to measure the concept. After consulting 10 experts in the field, 9 criteria with 25 items that are in line with the theoretical definition were finally identified. This includes the items introduced by the authors as well. Likert scale was used because vast majority of scales used in behavioral science in survey questionnaires are Likert scales that utilize an interval level of measurements (Cook et al., 
1981; Schmitt \& Klimoski, 1991 as cited in Hinkin et al., 1997). Measures with five or seven point scales have been shown to create adequate coefficient alpha that is necessary for internal consistency reliability estimates (Lissitz \& Green, 1975 as cited in Hinkin et al., 1997). Therefore, a 7 point Likert scale where $1=$ Strongly Disagree, $4=$ Neutral, $7=$ Strongly Agree, was used in the questionnaire in order to get wider variance of the opinions from the respondents.

Sample and procedure - Population is made up of ongoing road and building construction projects in Sri Lanka that are executed by the 10 largest contracting companies registered in Construction Development Authority of Sri Lanka. Therefore, a sample framework included 108 projects. Questionnaires were administrated to all 108 projects representing one participant from each project. Project Managers were the participants from the projects. Finally, 47 (44\% response rate) valid responses were received. Participants have $5-10$ years' experience in average and majority has a degree or more qualifications. Therefore, all the participants are qualified project management professionals with enough experience in the field. Out of 47 projects, $70 \%$ is building projects and road sector is accounted for $30 \%$. 25\% of building projects is public sector (client) projects while $46 \%$ is belongs to private sector ownership. Values of the projects range from SLR. 50 million to over 1,000 million. Average project value is between 501 to 1000 million. Therefore, sample covers projects from small, medium to large scale projects. Another important characteristic of the sample is physical status of the projects. Concerned projects range from mobilization stage to $100 \%$ completion stage. More than $60 \%$ has completed $50 \%$ of the physical work.

Validity - Validity is concerned with whether the right concept was measured (Sekaran \& Bougie, 2010; Zikmund et al., 2013). Further, Sekaran \& Bougie, (2010) stress the need for establishing three important validity types that are required for a measurement scale: content validity, criterion related validity and construct validity. Content/face validity ensures that the measure includes an adequate and representative set of items that tap the concept. To establish the content/face validity for this scale, previous studies were reviewed and all established items were included in the scale. Then those criteria and items were presented to 10 experts in the field representing both academics and practitioners. Overlapping and inconsistent items with definition were dropped in this process while ensuring content adequacy. Criterion related validity is established when the measure differentiate individual on a criterion it is expected to predict and this can be done by establishing concurrent validity or predictive validity (Sekaran \& Bougie, 2010). Accordingly, Concurrent validity occurs when the respondents score differently on the instrument. Predictive validity is about the ability of the measure to differentiate among individuals with reference to future criterion. Construct validity refers to how well the results obtained from the use of the measure fit the theories around which the test is designed and this is assessed through convergent and discriminant validity (Gerbing \& Anderson, 1988). Zikmund et al. (2013) define construct validity as the ability of a measure to confirm a network of related questions or hypotheses generated from literature based on concepts. Criterion validity and construct validity occur during the statistical analysis of the data. Correlational analysis is a measure that can be used to establish concurrent and predictive validity. Factor analysis is a useful measure to establish construct validity and it is a 
multivariate technique that confirms the dimensions of the concept that have been operationally defined, as well as indicating which of the items are most appropriate for each dimension (Sekaran \& Bougie, 2010). Therefore, in order to establish criterion and construct validity, the questionnaire was administrated to a sample and the correlational and factor analysis have been performed.

Reliability - Reliability of the measure indicates the extent to which it is without bias (error free) and hence ensure consistent measurement across time and across various items in the instrument (Sekaran \& Bougie, 2010). This is related to the internal consistency and the stability of the measure. The internal consistency of the measure is about the homogeneity of the items in the measure that tap the concept. Therefore, items should 'hang together' as a set and be capable of independently measuring the same concept so that the respondents attach the same overall meaning to each of the items (Sekaran \& Bougie, 2010). The most commonly accepted measure for assessing a scale internal consistency is Cronbach's alpha which tells how well the items measure the same construct (Price \& Mueller, 1986). Cronbach's alpha is a perfectly adequate index of the inter-items consistency reliability (Sekaran \& Bougie, 2010). Therefore, Cronbach's alpha has been calculated to establish the reliability of the scale. SPSS software package (version 22) has been used for the data analysis.

\section{Results and Discussion}

Table 2 includes the descriptive statistics for each items. There are 47 participants and no missing data were reported. The responses to each individual item have a fairly good spread. There are not outliers reported in the dataset.

Table 2: Descriptive Statistics

\begin{tabular}{|l|r|r|r|r|r|r|r|r|r|r|r|r|r|r|}
\hline & 1 & 2 & 3 & 4 & 5 & 6 & 7 & 8 & 9 & 10 & 11 & 12 & 13 \\
\hline $\mathrm{N}$ & Valid & 47 & 47 & 47 & 47 & 47 & 47 & 47 & 47 & 47 & 47 & 47 & 47 & 47 \\
& Missing & 0 & 0 & 0 & 0 & 0 & 0 & 0 & 0 & 0 & 0 & 0 & 0 & 0 \\
Mean & & 4.62 & 4.34 & 4.28 & 3.79 & 3.62 & 4.04 & 2.70 & 5.34 & 4.66 & 3.62 & 3.34 & 4.23 & 4.55 \\
Std. Deviation & 1.468 & 1.760 & 1.838 & 1.966 & 1.917 & 1.517 & 1.627 & 1.868 & 1.809 & 1.649 & 1.619 & 1.735 & 1.626 \\
Variance & 2.154 & 3.099 & 3.378 & 3.867 & 3.676 & 2.302 & 2.648 & 3.490 & 3.273 & 2.720 & 2.621 & 3.009 & 2.644 \\
Minimum & 1 & 1 & 1 & 1 & 1 & 1 & 1 & 1 & 1 & 1 & 1 & 1 & 1 \\
Maximum & 6 & 7 & 7 & 7 & 7 & 7 & 6 & 7 & 7 & 6 & 7 & 7 & 7 \\
\hline
\end{tabular}

\begin{tabular}{|ll|r|r|r|r|r|r|r|r|r|r|r|r|}
\hline & & 14 & 15 & 16 & 17 & 18 & 19 & 20 & 21 & 22 & 23 & 24 & 25 \\
\hline $\mathrm{N}$ & Valid & 47 & 47 & 47 & 47 & 47 & 47 & 47 & 47 & 47 & 47 & 47 & 47 \\
& Missing & 0 & 0 & 0 & 0 & 0 & 0 & 0 & 0 & 0 & 0 & 0 & 0 \\
Mean & & 4.49 & 4.32 & 4.19 & 4.98 & 5.00 & 4.43 & 4.49 & 4.66 & 4.32 & 4.43 & 4.57 & 5.02 \\
Std. Deviation & & 1.666 & 1.721 & 1.569 & 1.343 & 1.251 & 1.281 & 1.458 & 1.307 & 1.534 & 1.529 & 1.931 & 1.635 \\
Variance & & 2.777 & 2.961 & 2.463 & 1.804 & 1.565 & 1.641 & 2.125 & 1.708 & 2.352 & 2.337 & 3.728 & 2.673 \\
Minimum & 1 & 1 & 1 & 1 & 2 & 1 & 1 & 1 & 1 & 1 & 1 & 1 \\
Maximum & & 7 & 7 & 7 & 7 & 7 & 6 & 7 & 7 & 7 & 7 & 7 & 7 \\
\hline
\end{tabular}

According to Kaiser \& Rice (1974), KMO measure of sample adequacy is an adequate indicator to see the sample adequacy in order to perform a factor analysis. Accordingly, if the value is .90s - Marvelous, 80 s - Meritorious, .70s - Meddling, .60s - 
Mediocre. In the Table 3, KMO value is .675 which is greater than mediocre level and it is closer to meddling level. Further, it could be noted, that according to Bartlett's Test of Sphericity, the $P$-value is .000 which is less than 0.05 . Therefore, it is statistically significant and possible to conduct a factor analysis without any difficulty.

Table 3: KMO and Bartlett's Test

\begin{tabular}{|ll|l|}
\hline Kaiser-Meyer-Olkin Measure of Sampling Adequacy. & 675 \\
Bartlett's Test ofApprox. Chi-Square & 869.168 \\
Sphericity & df & 300 \\
& Sig. & .000 \\
\hline
\end{tabular}

According to Kim \& Mueller (1978), it is important to investigate the inter-item correlations among the variables before doing a factor analysis, because Churchill (1979), mentions that low correlations are producing error and unreliability. Table 4 - Correlation Matrix indicates how an item is correlated with other items of the scale. It is observable that majority of the items is sufficiently correlated with other items and the determinant value is 5.647 which is greater than .0001 . However, it could be noted that some of the items have low correlation values which are closer to zero. Further, communalities represent the relation between the variable and all other variables. According to the Table 5, vast majority of the items have communality values greater than .04 while some of the communality values are lower than that. This outcome suggests that some items do not share equally in the common core and should be eliminated (Churchill, 1979). Further, it was found that some items are inappropriately loading (cross loading) with some other factors. Hinkin et al. (1997), explain that only those items that clearly load on a single factor should be retained. According to them, retaining items should have factor loadings greater than .04 or/and the factor loadings should be twice stronger on the appropriate factor than other factor. Therefore, problematic items were dropped.

Table 4: Correlational Matrix

\begin{tabular}{|c|c|c|c|c|c|c|c|c|c|c|c|c|c|c|c|c|c|c|c|c|c|c|c|c|c|c|}
\hline \multicolumn{27}{|c|}{ Correlation Matrix ${ }^{\mathrm{a}}$} \\
\hline & & 1 & 2 & 3 & 4 & 5 & 6 & 7 & 8 & 9 & 10 & 11 & 12 & 13 & 14 & 15 & 16 & 17 & 18 & 19 & 20 & 21 & 22 & 23 & 24 & 25 \\
\hline irrelatio & 1 & 1.000 & .632 & -.100 & .370 & .348 & .154 & -.258 & .152 & .425 & .234 & .129 & .138 & .209 & .096 & .377 & .268 & .128 & .118 & .308 & .303 & .248 & .316 & .268 & .187 & .311 \\
\hline n & 2 & .632 & 1.000 & $\mid-.419$ & .348 & .484 & .174 & -351 & $\mid-.069$ & .221 & 248 & .264 & $\mid-.034$ & .221 & .283 & .250 & . 149 & .003 & .010 & .175 & .171 & .155 & .442 & .454 & \begin{tabular}{|l|}
-.033 \\
\end{tabular} & .073 \\
\hline & 3 & -.100 & -.419 & 1.000 & -.320 & \begin{tabular}{|l|}
-.364 \\
\end{tabular} & $\mid-.121$ & .312 & .200 & 107 & $|-151|$ & $\mid-.208$ & 313 & -.205 & -.379 & .068 & \begin{tabular}{|l|}
-.004 \\
\end{tabular} & .038 & .123 & .041 & .030 & .004 & -.171 & $|-.074|$ & .009 & $\mid-.038$ \\
\hline & 4 & .370 & .348 & -.320 & 1.000 & .877 & .069 & -299 & 103 & .224 & .598 & .399 & .104 & .323 & .384 & .329 & .359 & .352 & .283 & .304 & .378 & .369 & .513 & .486 & .107 & .231 \\
\hline & 5 & .348 & .484 & $\mid-.364$ & .877 & 1.000 & .036 & -.302 & .001 & .200 & .578 & .407 & .093 & .223 & .284 & .394 & .307 & .233 & .190 & .263 & .356 & .346 & .626 & .606 & .002 & 169 \\
\hline & 6 & .154 & . 174 & -.121 & .069 & .036 & 1.000 & .023 & . 1117 & .227 & \begin{tabular}{|l|}
-.028 \\
\end{tabular} & .074 & .054 & .202 & .232 & .011 & . 124 & .203 & . 172 & .214 & .089 & .194 & .059 & .161 & .303 & .376 \\
\hline & 7 & -.258 & $\mid-.351$ & .312 & -.299 & \begin{tabular}{|l|l} 
\\
\end{tabular} & .023 & 1.000 & .034 & --.109 & \begin{tabular}{|l|}
-.084 \\
\end{tabular} & \begin{tabular}{|l|l|} 
\\
\end{tabular} & $\mid-.006$ & $|-.544|$ & \begin{tabular}{|c|} 
\\
\end{tabular} & -.229 & $|-.301|$ & -341 & \begin{tabular}{|l|}
-.192 \\
\end{tabular} & $\mid-345$ & -.414 & -.325 & -.353 & -.263 & -.138 & $\mid-.120$ \\
\hline & 8 & .152 & $\mid-.069$ & .200 & .103 & .001 & . 117 & .034 & 1.000 & .556 & .128 & $\mid-.010$ & .129 & .309 & .364 & 290 & . 304 & .332 & 214 & .429 & .329 & 209 & .105 & .268 & .427 & .375 \\
\hline & 9 & .425 & .221 & .107 & .224 & .200 & .227 & -109 & .556 & 1.000 & .130 & \begin{tabular}{|l}
-.056 \\
\end{tabular} & 158 & .391 & .201 & .217 & .307 & .435 & 307 & .495 & .444 & .410 & .330 & .439 & .499 & .546 \\
\hline & 10 & .234 & 248 & $|-.151|$ & .598 & .578 & -.028 & -.084 & . 128 & . 130 & 1.000 & .595 & .032 & .137 & .354 & .266 & .231 & .242 & .284 & .243 & .242 & .200 & .359 & .437 & $|-.086|$ & .140 \\
\hline & 11 & .129 & .264 & $\mid-208$ & .399 & .407 & .074 & -.027 & \begin{tabular}{|l|l|} 
\\
$\mid$
\end{tabular} & -0.056 & .595 & 1.000 & .312 & $|-.007|$ & .267 & .241 & .290 & . 153 & 268 & .285 & .232 & .128 & .306 & .336 & -154 & -.085 \\
\hline & 12 & 138 & $\mid-.034$ & .313 & .104 & .093 & .054 & -.006 & .129 & 158 & .032 & .312 & 1.000 & .200 & \begin{tabular}{|l}
-.093 \\
\end{tabular} & .339 & .215 & .338 & 301 & .248 & 203 & .065 & . 1118 & .150 & . 121 & $\mid-.078$ \\
\hline & 13 & .209 & 221 & $\mid-205$ & .323 & .223 & .202 & $|-.544|$ & .309 & .391 & .137 & \begin{tabular}{|l|l|} 
\\
\end{tabular} & .200 & 1.000 & .387 & .340 & .545 & .633 & .449 & .626 & 617 & .510 & . 346 & .411 & .264 & .241 \\
\hline & 14 & .096 & 283 & $\mid-.379$ & .384 & .284 & .232 & \begin{tabular}{|l|} 
\\
\end{tabular} & .364 & .201 & .354 & .267 & $\mid-093$ & .387 & 1.000 & . 346 & .446 & .403 & 365 & .430 & .499 & .458 & .533 & .531 & 350 & .291 \\
\hline & 15 & .377 & .250 & .068 & .329 & .394 & .011 & -.229 & .290 & .217 & .266 & .241 & .339 & .340 & .346 & 1.000 & .814 & .436 & .535 & .440 & .534 & .513 & .512 & .534 & . 356 & .322 \\
\hline & 16 & .268 & .149 & $|-.004|$ & .359 & .307 & .124 & -301 & .304 & .307 & .231 & .290 & .215 & .545 & .446 & .814 & 1.000 & .621 & .653 & .651 & 671 & .637 & .525 & .545 & .422 & .346 \\
\hline & 17 & .128 & .003 & .038 & .352 & .233 & .203 & -341 & .332 & .435 & .242 & .153 & .338 & .633 & .403 & .436 & .621 & 1.000 & .776 & .574 & .627 & .615 & .341 & .375 & .231 & .347 \\
\hline & 18 & .118 & .010 & .123 & .283 & 190 & . 172 & -192 & .214 & .307 & .284 & .268 & 301 & .449 & . 365 & .535 & .653 & . 776 & $\mid 1.000$ & .583 & .596 & .598 & 295 & .352 & .171 & .340 \\
\hline & 19 & .308 & . 175 & .041 & .304 & .263 & .214 & -.345 & .429 & .495 & .243 & .285 & 248 & .626 & .430 & .440 & .651 & .574 & .583 & 1.000 & .841 & .673 & .516 & .538 & 391 & .411 \\
\hline & 20 & .303 & .171 & .030 & .378 & .356 & .089 & -.414 & .329 & .444 & .242 & .232 & .203 & .617 & .499 & .534 & .671 & .627 & .596 & .841 & 1.000 & .831 & .668 & .607 & .431 & .415 \\
\hline & 21 & .248 & .155 & .004 & .369 & .346 & .194 & -.325 & .209 & .410 & .200 & .128 & .065 & .510 & .458 & .513 & .637 & .615 & .598 & .673 & .831 & 1.000 & .576 & .586 & . 398 & .553 \\
\hline & 22 & .316 & .442 & $|-.171|$ & .513 & .626 & .059 & $-.353 \mid$ & .105 & .330 & .359 & .306 & .118 & .346 & .533 & .512 & .525 & .341 & .295 & .516 & .668 & .576 & 1.000 & .896 & .392 & .214 \\
\hline & 23 & .268 & .454 & $|-.074|$ & .486 & .606 & .161 & -.263 & .268 & .439 & .437 & .336 & . 150 & .411 & .531 & .534 & .545 & .375 & 352 & .538 & .607 & .586 & .896 & 1.000 & .328 & .249 \\
\hline & 24 & . 187 & \begin{tabular}{|c|c|} 
\\
\end{tabular} & .009 & . 107 & .002 & .303 & -138 & .427 & .499 & -.086 & -.154 & . 121 & .264 & .350 & .356 & .422 & .231 & . 171 & .391 & .431 & .398 & .392 & .328 & $\mid$\begin{tabular}{|l|}
$\mid$ \\
\end{tabular} & .581 \\
\hline & 25 & .311 & .073 & \begin{tabular}{|l|l|} 
\\
\end{tabular} & .231 & .169 & .376 & -120 & .375 & .546 & .140 & \begin{tabular}{|l}
-.085 \\
\end{tabular} & \begin{tabular}{|l}
-078 \\
\end{tabular} & .241 & 291 & .322 & .346 & .347 & .340 & .411 & .415 & .553 & .214 & .249 & .581 & 1.000 \\
\hline
\end{tabular}




\section{Table 5: Communalities}

\begin{tabular}{|c|c|c|}
\hline \multicolumn{3}{|c|}{ Communalities } \\
\hline & Initial & Extraction \\
\hline 1 & 1.000 & .316 \\
\hline 2 & 1.000 & .609 \\
\hline 3 & 1.000 & .512 \\
\hline 4 & 1.000 & .648 \\
\hline 5 & 1.000 & .757 \\
\hline 6 & 1.000 & .220 \\
\hline 7 & 1.000 & .257 \\
\hline 8 & 1.000 & .381 \\
\hline 9 & 1.000 & .538 \\
\hline 10 & 1.000 & .516 \\
\hline 11 & 1.000 & .570 \\
\hline 12 & 1.000 & .390 \\
\hline 13 & 1.000 & .473 \\
\hline 14 & 1.000 & .434 \\
\hline 15 & 1.000 & .547 \\
\hline 16 & 1.000 & .702 \\
\hline 17 & 1.000 & .658 \\
\hline 18 & 1.000 & .674 \\
\hline 19 & 1.000 & .701 \\
\hline 20 & 1.000 & .769 \\
\hline 21 & 1.000 & .667 \\
\hline 22 & 1.000 & .659 \\
\hline 23 & 1.000 & .659 \\
\hline 24 & 1.000 & .600 \\
\hline 25 & 1.000 & .581 \\
\hline
\end{tabular}

Scree-pot (Figure 1), Eigenvalues, Total Variance Explained (Table 6) and the literature have been used to decide the number of factors to be extracted. According to Hinkin et al. (1997), percentage of variance explained that are looking for is greater than $60 \%$. If the extracted factors could explain $60 \%$ of the total variance it could be considered as a minimum acceptable level. Therefore, extracted three-factor-solution is appropriate because these three factors explain $62.75 \%$ of the variance of the construct of construction project success (Table 6). It is believed that this three-factor-solution is simple, parsimonious and in line with the literature.

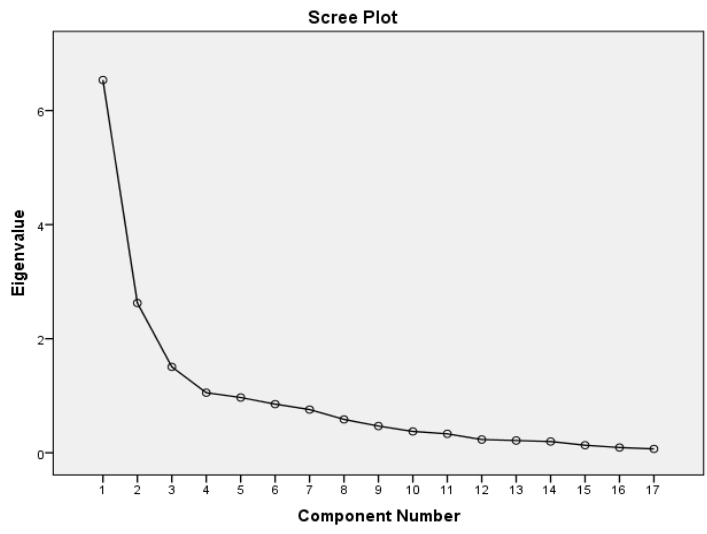

Figure 1: Scree plot 


\section{Table 6: Total Variance Explained}

\begin{tabular}{|c|c|c|c|c|c|c|c|c|c|}
\hline \multirow[b]{2}{*}{ Component } & \multicolumn{3}{|c|}{ Initial Eigenvalues } & \multicolumn{3}{|c|}{$\begin{array}{l}\text { Extraction Sums of } \\
\text { Squared Loadings }\end{array}$} & \multicolumn{3}{|c|}{$\begin{array}{l}\text { Rotation Sums of } \\
\text { Squared Loadings }\end{array}$} \\
\hline & Total & $\begin{array}{c}\% \text { of } \\
\text { Variance }\end{array}$ & $\begin{array}{c}\text { Cumu } \\
\text { lative } \\
\%\end{array}$ & Total & $\begin{array}{c}\text { \% of } \\
\text { Varian } \\
\text { ce }\end{array}$ & $\begin{array}{c}\text { Cumu } \\
\text { lative } \\
\%\end{array}$ & Total & \begin{tabular}{|c|}
$\%$ of \\
Varian \\
ce
\end{tabular} & $\begin{array}{c}\text { Cumu } \\
\text { lative } \\
\%\end{array}$ \\
\hline 1 & 6.535 & 38.444 & 38.44 & 6.535 & 38.44 & 38.44 & 4.763 & 28.02 & 28.02 \\
\hline 2 & 2.626 & 15.447 & 53.89 & 2.626 & 15.45 & 53.89 & 3.044 & 17.91 & 45.92 \\
\hline 3 & 1.506 & 8.859 & 62.75 & 1.506 & 8.859 & 62.75 & 2.861 & 16.83 & 62.75 \\
\hline 4 & 1.054 & 6.197 & 68.95 & & & & & & \\
\hline 5 & 0.969 & 5.698 & 74.65 & & & & & & \\
\hline 6 & 0.853 & 5.02 & 79.67 & & & & & & \\
\hline 7 & 0.758 & 4.457 & 84.12 & & & & & & \\
\hline 8 & 0.585 & 3.443 & 87.57 & & & & & & \\
\hline 9 & 0.469 & 2.759 & 90.33 & & & & & & \\
\hline 10 & 0.374 & 2.199 & 92.52 & & & & & & \\
\hline 11 & 0.333 & 1.956 & 94.48 & & & & & & \\
\hline 12 & 0.232 & 1.367 & 95.85 & & & & & & \\
\hline 13 & 0.215 & 1.268 & 97.12 & & & & & & \\
\hline 14 & 0.197 & 1.158 & 98.27 & & & & & & \\
\hline 15 & 0.133 & 0.781 & 99.05 & & & & & & \\
\hline 16 & 0.092 & 0.543 & 99.6 & & & & & & \\
\hline 17 & 0.069 & 0.403 & 100 & & & & & & \\
\hline
\end{tabular}

In this process factor analysis was iterated until an appropriate scale was found. Finally, only 17 items were retained and those items are appropriately loading on three factors (Table 7: Rotated Component Matrix). The method used for extraction is Principal Component Analysis and rotation method is Varimax with Kaiser Normalization. Accordingly, Rotated Component Metrix shows factor loadings of each item and all the loadings are greater than .04 .

Table 7: Rotated Component Matrix

\begin{tabular}{|l|l|l|l|}
\hline \multicolumn{2}{|l|}{ Component } & \multicolumn{2}{l|}{} \\
\cline { 2 - 4 } & 1 & 2 & 3 \\
\hline New expertise development & .842 & & \\
Confidence gained & .834 & & \\
Positive reputation in the market & .815 & & \\
New work techniques exploration & .786 & & \\
Professional development of employees & .768 & & \\
New business contacts & .738 & & \\
Client's complains management & .665 & & \\
Overall time schedule & & .886 & \\
Construction speed & & .823 & .749 \\
Billing performance & & .636 & .762 \\
Overall cost & & .632 & .755 \\
Cash-flow management & & & .738 \\
Lost days due to environmental issues & & & .556 \\
Penalty on environmental issues & & & \\
Lost days due to accidents & & & \\
Accident rate & & & \\
Meeting technical specifications & & & \\
\hline
\end{tabular}

Extraction Method: Principal Component Analysis. Rotation Method: Varimax with Kaiser Normalization. 
According to Table 8, communality values for finally retained items are greater than 0.4 which shows that each item sufficiently correlates with other items. Thus these items equality share the common core of the construct that is intended to measure.

Table 8: Communalities for Finally Retained Items

\begin{tabular}{|l|l|l|}
\hline Items & Initial & Extraction \\
\hline Overall cost & 1.000 & .455 \\
\hline Construction speed & 1.000 & .756 \\
\hline Overall time schedule & 1.000 & .817 \\
\hline Meeting technical specifications & 1.000 & .414 \\
\hline Accident rate & 1.000 & .418 \\
\hline Lost days due to accidents & 1.000 & .644 \\
\hline Billing performance & 1.000 & .615 \\
\hline Cash-flow management & 1.000 & .541 \\
\hline Client's complains management & 1.000 & .522 \\
\hline New work techniques exploration & 1.000 & .685 \\
\hline Confidence gained & 1.000 & .727 \\
\hline New expertise development & 1.000 & .719 \\
\hline Professional development of employees & 1.000 & .733 \\
\hline Positive reputation in the market & 1.000 & .788 \\
\hline New business contacts & 1.000 & .692 \\
\hline Lost days due to environmental issues & 1.000 & .654 \\
\hline Penalty on environmental issues & 1.000 & .648 \\
\hline
\end{tabular}

Reliability statistics - Reliability of a measure indicates the extent to which it is without bias (error free) and hence ensures consistent measurement across time and across varies items in the measurement (Sekaran \& Bougie, 2010). Most commonly accepted method for assessing internal consistency reliability is Cronbach's alpha (Price \& Mueller, 1986). Cronbach's alpha is computed in terms of the average inter-correlations among the items measuring the concept. Cronbach's Alpha is considered as a valid indicator of inter-items consistency reliability. Higher the Cronbach's coefficient alpha, the better the measurement. Hinkin et al. (1997) highlights that the Cronbach's coefficient alpha greater than .07 is desirable. According to Churchill (1979), it is an indication of strong homogeneity and suggesting that sampling domain has been captured adequately. According to the reliability statistics (Table 9), Cronbach's Alpha value is .887 for overall scale. Therefore, it indicates a good inter-items correlation. This test was performed separately for each factor and results indicate a good inter-items consistency reliability for each factor that were extracted ( $1^{\text {st }}$ Factor $-0.924,2^{\text {nd }}$ Factor 0.822 and $3^{\text {rd }}$ Factor -0.808 ).

According to the results of this study, three factors with 17 items have been identified. $2^{\text {nd }}$ and $3^{\text {rd }}$ factors represent two facets of the efficiency dimension of the conception of Silva et al. (2016). It is clearly observable that items loaded on $2^{\text {nd }}$ and $3^{\text {rd }}$ factors are related to project management efficiency which Silva et al. (2016) refer to efficiency dimension. Further, it is observable that the items that are loaded together on $3^{\text {rd }}$ factor are related to meeting the requirement of safety, environmental and quality standards. These are often considered as the compliance requirements that the project 
management organization should adhere to in the process of project execution. Items loaded on $2^{\text {nd }}$ factors are about the project implementation efficiency.

Table 9: Reliability Statistics

\begin{tabular}{|l|l|l|}
\hline Factor & $\begin{array}{l}\text { Cronbach's Alpha Based on } \\
\text { Standardized Items }\end{array}$ & N of Items \\
\hline Overall scale & 0.887 & 17 \\
\hline $1^{\text {st }}$ Factor & 0.924 & 7 \\
\hline $2^{\text {nd }}$ Factor & 0.822 & 5 \\
\hline $3^{\text {rd }}$ Factor & 0.808 & 5 \\
\hline
\end{tabular}

Therefore, these two factors could be labeled as Project Implementation Efficiency ( $2^{\text {nd }}$ factor) and Compliance Management Efficiency ( $3^{\text {rd }}$ factor). $1^{\text {st }}$ factor is more future oriented and therefore related to long term perspective (effectiveness) of the conception of Silva et al. (2016). Therefore, $1^{\text {st }}$ factor could be rationally labeled as Preparing for Future. Therefore, dimension of Project Implementation Efficiency could be defined as the degree of compilation of construction work within the estimated budget, time schedule and cashflow targets and this dimension could be measured with 5 items. Dimension of Project Compliance Management Efficiency could be defined as the degree of compliance to quality, safety and environmental standards and it could be measured with 5 items. Dimension of Preparing for Future could be defined as the degree of achievements in terms of new expertise, confidence, reputation, new work techniques, employee development, new business contacts and the satisfaction of the client in order to be successful in future and this could be measured with 7 items.

\section{Conclusion and Recommendations}

Construction industry is largely dependent on a project based management strategy. Generally, construction project management researches are evolving around the concept of project success because project success is the central concern of all parties. However, unavailability of an appropriate measure that could be used in present context has been a long outstanding issue. Therefore, this study has attempted to fill this void by developing a measurement scale with high validly and reliability. This paper has identified a three dimensional scale that has more parsimony and in line with literature in order to measure perceived construction project success. This measurement scale will be instrumental for academics that are aspired to do their researches in construction context. Further, this framework (Figure 02) could be used as a valid guideline for project management professionals and construction companies to dive their projects for achieving greater success. Also, future researches can test this scale in other country context and with larger sample in order to increase the validity and reliability of the scale. 


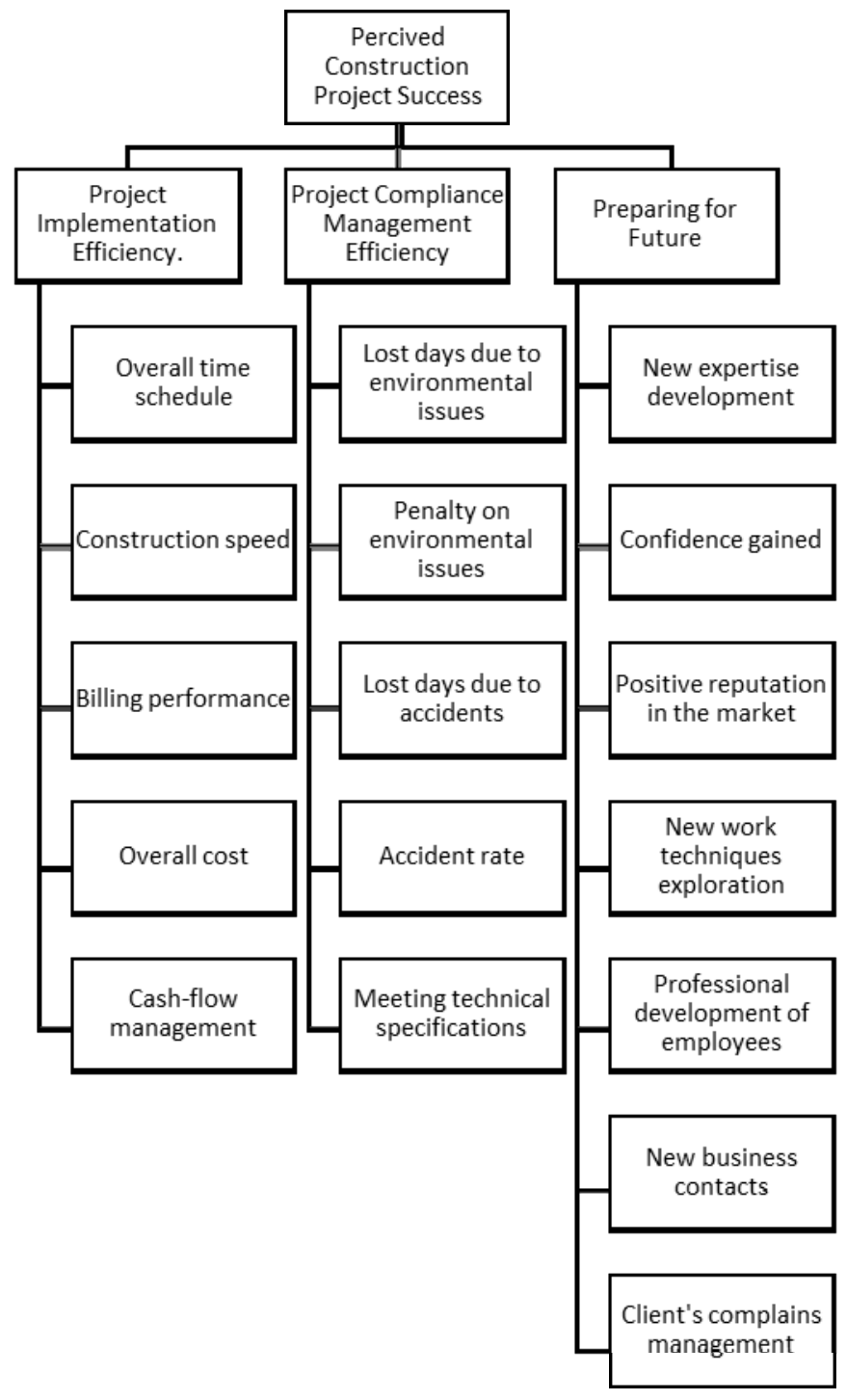

Figure 2: Framework for Measuring Construction Project Success

\section{References}

Al-Tmeemy, S. M. H. M., Abdul-Rahman, H., Harun, Z. (2011), Future criteria for success of building projects in Malaysia, International Journal of Project Management, Vol. 29, no. 3, pp. 337348.

Atkinson, R. (1999), Project management: cost, time and quality, two best guesses and a phenomenon, its time to accept other success criteria, International journal of project management, Vol. 17, no. 6, pp. 337-342.

Baccarini, D. (1999), The logical framework method for defining project success, Project management journal, Vol. 30, no. 4, pp. 25-32.

Baker, B. N., Murphy, D. C., Fisher, D. (2008), Factors affecting project success, Project Management Handbook, Second Edition, pp. 902-919. 
Bannerman, P. L. (2008, July), Defining project success: a multilevel framework, In Proceedings of the Project Management Institute Research Conference, pp. 1-14.

Belout, A. (1998), Effects of human resource management on project effectiveness and success: toward a new conceptual framework, International Journal of Project Management, Vol. 16, no. 1, pp. 21-26.

Chan, A. P., Chan, A. P. (2004), Key performance indicators for measuring construction success, Benchmarking: an international journal, Vol. 11, no. 2, pp. 203-221.

Chen, H. L. (2012), Predictor of project Performance and the Likelihood of Project Success, available online at http:/www.jimsjournal.org.

Cheong Yong, Y., Emma Mustaffa, N. (2012), Analysis of factors critical to construction project success in Malaysia, Engineering, Construction and Architectural Management, Vol. 19, no. 5, pp. 543-556.

Chovichien, V., Nguyen, T. A. (2013). List of indicators and criteria for evaluating construction project success and their weight assignment. In Proceedings of the 4th International Conference on Engineering, Project, and Production Management (EPPM 2013), pp. 130-150.

Churchill Jr, G. A. (1979), A paradigm for developing better measures of marketing constructs, Journal of marketing research, pp. 64-73.

Cooke-Davies, T. (2002), The "real" success factors on projects, International journal of project management, Vol. 20, no. 3, pp. 185-190.

De Wit, A. (1988), Measurement of project success. International journal of project management, Vol. 6, no. 3, pp.164-170.

Elattar, S. M. S. (2009), Towards developing an improved methodology for evaluating performance and achieving success in construction projects, Scientific Research and Essays, Vol. 4, no. 6, pp. 549-554.

Garbharran, H., Govender, J., Msani, T. (2012), Critical success factors influencing project success in the construction industry, Acta Structilia, Vol. 19, no. 2, pp. 90-108.

Gerbing, D. W., Anderson, J. C. (1988), An updated paradigm for scale development incorporating unidimensionality and its assessment, Journal of marketing research, pp. 186-192.

Gunasekera, H. A. D. P. M. (2009), Managing critical factors in construction projects: applicability of compensatory model for effective project management, A Thesis Submitted in partial fulfillment of the Requirements of Sri Jayewardenepura University for the Degree of Doctor of Philosophy.

Han, W. S., Yusof, A. M., Ismail, S., Aun, N. C. (2011), Reviewing the notions of construction project success, International Journal of Business and Management, Vol. 7, no. 1, pp. 90 - 105.

Heravi, G., Ilbeigi, M. (2012), Development of a comprehensive model for construction project success evaluation by contractors, Engineering, Construction and Architectural Management, Vol.19, no. 5, pp. 526-542.

Hinkin, T. R., Tracey, J. B., Enz, C. A. (1997), Scale construction: Developing reliable and valid measurement instruments, Journal of Hospitality \& Tourism Research, Vol. 21, no. 1, pp. 100-120.

Hughes, S. W., Tippett, D. D., Thomas, W. K. (2004), Measuring project success in the construction industry, Engineering Management Journal, Vol.16, no. 3, pp. 31-37.

Kaiser, H. F., Rice, J. (1974), Little jiffy, mark IV. Educational and psychological measurement, Vol. 34, no. 1, pp. 111-117.

Khosravi, S., Afshari, H. (2011), A success measurement model for construction projects, In International Conference on Financial Management and Economics, Vol. 11, pp. 186-190.

Kim, J. O., Muller, C. W. (1978), Introduction to Factor Analysis: What It Is and How To Do It, Series: Quantitative Applications in the Social Sciences. Beverly Hills, CA: Sage. 
Lim, C. S., Mohamed, M. Z. (1999), Criteria of project success: an exploratory re-examination, International journal of project management, Vol. 17, no. 4, pp. 243-248.

Müller, R., Jugdev, K. (2012), Critical success factors in projects: Pinto, Slevin, and Prescott-the elucidation of project success, International Journal of Managing Projects in Business, Vol. 5, no. 4, pp. 757-775.

Parfitt, M. K., Sanvido, V. E. (1993), Checklist of critical success factors for building projects, Journal of Management in Engineering, Vol. 9, no. 3, pp. 243-249.

Pinto, J. K., Slevin, D. P. (1988), Project success: definitions and measurement techniques, Project Management Institute.

Price, J.L. Mueller, C. W. (1986), Handbook of organizational measurement. Marshfield, MA: Pitman Publishing.

Sekaran, U., Bougie, R. (2016), Research methods for business: A skill building approach, John Wiley \& Sons.

Serrador, P., Turner, J. R. (2014), The relationship between project success and project efficiency, Procedia-Social and Behavioral Sciences, Vol. 119, pp. 75-84.

Shenhar, A. J., Dvir, D., Levy, O., \& Maltz, A. C. (2001), Project success: a multidimensional strategic concept, Long range planning, Vol. 34, no. 6, pp. 699-725.

Silva, G. A., Warnakulasooriya, B. N. F., Arachchige, B. J. (2016), Criteria for Construction Project Success: A Literature Review, In 14th Internally conference on business management, Sri Lanka: ICBM2014.

Tabish, S., Jha, K. N. (2011), Important factors for success of public construction projects, In 2nd International Conference on Construction and Project Management IPEDR, Singapore: IACSIT Press.

Takim, R., Adnan, H. (2009), Analysis of effectiveness measures of construction project success in Malaysia, Asian Social Science, Vol. 4, no. 7, pp. 74-86

Tranfield, D., Denyer, D., Smart, P. (2003), Towards a methodology for developing evidence-informed management knowledge by means of systematic review, British journal of management, Vol. 14, no. 3, pp. 207-222.

Turner, R., Zolin, R. (2012), Forecasting success on large projects: developing reliable scales to predict multiple perspectives by multiple stakeholders over multiple time frames, Project Management Journal, Vol. 43, no. 5, pp. 87-99.

Wai, S. H., Yusof, A. M., Ismail, S. (2012), Exploring success criteria from the developers' perspective in Malaysia, International Journal of Engineering Business Management, Vol. 4, no. 3.

Zikmund, W. G., Babin, B. J., Carr, J. C., Griffin, M. (2013). Business research methods. Cengage Learning. 